\title{
Novels and Essays: South Africa in the Work of Olive Schreiner
}

\section{Susan Barrett}

\section{(2) OpenEdition \\ 1 Journals}

Electronic version

URL: https://journals.openedition.org/ces/8737

DOI: $10.4000 /$ ces.8737

ISSN: 2534-6695

Publisher

SEPC (Société d'études des pays du Commonwealth)

\section{Printed version}

Date of publication: 1 September 2009

Number of pages: 87-97

ISSN: 2270-0633

\section{Electronic reference}

Susan Barrett, "Novels and Essays: South Africa in the Work of Olive Schreiner", Commonwealth Essays and Studies [Online], 32.1 | 2009, Online since 23 December 2021, connection on 17 February 2022. URL: http://journals.openedition.org/ces/8737 ; DOI: https://doi.org/10.4000/ces.8737

\section{(c) (i) $\odot$}

Commonwealth Essays and Studies is licensed under a Licence Creative Commons Attribution - Pas d'Utilisation Commerciale - Pas de Modification 4.0 International. 


\section{Novels and Essays: South Africa in the Work of Olive Schreiner}

This paper looks at the way South Africa is portrayed in the novels and essays of Olive Schreiner. It argues that while Schreiner's essays were unusual in that she defended the cause of the Boers during the Boer war, her fiction was far more radical. It suggests that her lasting legacy is her innovative description of the South African landscape which paved the way for the development of New Literatures in English.

Today the South African writer Olive Schreiner is remembered almost exclusively for a single work of fiction, The Story of an African Farm, which is considered by literary historians to be "the first novel written by a colonial to be warmly and widely acclaimed in Britain" (Laredo 107). During her own lifetime, however, she was a prominent and controversial figure and her polemical essays were as well known as her novel. Her book, Women and Labour, published in 1911, secured her reputation as a fearsome feminist while her criticism of British imperial policy and her defence of the Boers in a series of essays and public meetings earned her the nickname "Olive (firebrand) Schreiner" (Schoeman 128). In both her novels and her essays on South Africa, landscape plays an important role. As postcolonial theory has shown, naming space is a symbolic appropriation of land (Darian-Smith 3), and when Schreiner was writing it was the English who were doing the appropriating.

At the end of the nineteenth century, Africa was very much in favour with British readers: books by and about David Livingstone, for example, became "best sellers," with Morton Stanley's In Darkest Africa selling 150000 copies in the 1890s (Boehmer 31). Adventure stories were at the height of their popularity. Novels such as those by Henry Rider Haggard, John Buchan and Robert Louis Stevenson sold extremely well and over fifty children's journals devoted solely to "manly adventures" for boys were founded between 1880 and 1890 (Zhuwarara 23). The description of Africa in all these books, regardless of whether they were fictional or factual, was a reflection of British imperialism. As Martin Green says of adventure stories: "They were, collectively, the story England told itself as it went to sleep at night; and in the form of its dreams, they charged England's will with the energy to go out into the world and explore, conquer and rule" (Green 3).

Seen through European eyes, Africa was an exotic place where the protagonist could prove his manhood and make enough money to return and settle in England. It was seen neither as a place in which civilised people could live permanently nor as a setting for anything but popular fiction. This presented the young Olive Schreiner with a dilemma. Since she intended to write 'serious' literature she could 
not place her characters in the African landscape with which she was familiar and, as a result, set over half of her first novel Undine in England, a country she had never visited. Her knowledge of England came from the English novels she had read and the stories her mother had told her about English childhoods. The descriptions of England in Undine are interesting, precisely because they are so un-English. I suggest they can be read as some of the earliest examples of the colonial looking back at the coloniser and they unwittingly illustrate some of the fundamental differences between England and Africa ${ }^{1}$. In Schreiner's England plants grow too fast: "The flowers opened their eyes by thousands. [T] he tender plants shot out of the moist ground through every crack" (139) and insect life is surprisingly abundant: "among its knotted swollen roots, the bright backed beetles and busy ants would run" (111). Above all there is too much sun and too much light. In the summer the sky is invariably blue, more often than not "clear blue with not one tell-tale cloud" (114). The word "hazy," which is more usually associated with a British summer, occurs only once (56). The most frequent adjectives are "bright", "shimmering" and above all "glittering;" "the hills all green and glittering in the morning light" (60), "the great glittering dew drops" (73), "its roof glittering in the sunshine" (75). Winter scenes are often little more than clichés; the narrator talks, for example, of "the leaden sky and leafless trees" (93). Only one description shows any originality but once again the light, this time the moonlight, clearly belongs to Africa: "The snow had fallen, the clouds had gone and the full moon poured down her light on a white, glittering world - so white, so pure, so calm" $(104)^{2}$.

When Undine wonders whether things which occur in both England and Africa really are the same, she is giving voice to something which must have preoccupied Schreiner: "She wondered if the dew lying on the English grass were really as lovely as the great drops that used to stand trembling on the bushes and silvery ice-plants among the stones of the Koppie" (73). The way the comparison is constructed underlines her African origins. Undine is looking for signs of Africa in England whereas writers such as Rider Haggard were constantly looking for signs of England in Africa: "Its climate was quite cold, not at all unlike that of England. Indeed for the first three days of our stay there we saw little or nothing of the scenery on account of an unmistakable Scotch mist which prevailed" (99).

After Schreiner had finished the novel, she appears to have had second thoughts about her English scenes. Her second novel, The Story of an African Farm, is set entirely in Africa. It reuses many of the African scenes from Undine,

1. The examples which follow are borrowed from an earlier article in which I discuss how South Africans have written about England. See S. Barrett, "Oh to be in Africa now that April's there: Demythologising the Motherland in White South African Women's Writing".

2. Compare this to the opening sentence of The Story of an African Farm: "The full African moon poured down its light from the blue sky into the wide, lonely plain" (35). 
and Schreiner later asked those with copies of the manuscript of Undine to destroy them. Describing the Africa with which she was familiar brought with it different problems, for the arid karoo in which Schreiner lived was nothing like the Africa in the books English people were used to reading. As David Bunn has pointed out, after 1850 Africa began to be associated in the British reader's mind with East Africa, because that was where Britain's trading interests lay (7). Precise events within books about Africa differed, but most tended to follow a similar pattern with the hero undertaking a journey from the coast inland, usually along a river, which was both a metaphor of free trade and a symbol of the mythical and mysterious interior of the continent (ibidem). Vegetation was invariably dense and luxuriant and the following description of Kekunaland, a thinly veiled Zululand, from Rider Haggard's King Solomon's Mines, is typical of many novels of the period:

some five thousand feet beneath where we stood, lay league on league of the most lovely champaign country. Here were dense patches of lofty forest, there a great river wound its silvery way. To the left stretched a vast expanse of rich undulating veldt or grass land, on which we could just make out countless herds of game or cattle, at that distance we could not tell which [...] The landscape lay before us as a map, in which rivers flashed like silver snakes, and Alp-like peaks crowned with wildly twisted snow wreaths rose in solemn grandeur, whilst over all was the glad sunlight and the wide breath of Nature's happy life. (95)

It is worth examining in some detail the vocabulary Rider Haggard uses. There is an attempt to render the unfamiliar familiar. The narrator suggests that "veldt" is the same thing as "grass land", that "game" might only be "cattle" and that the mountains are like the Alps. This reference to the "Alps," together with words such as "lofty" and "grandeur," is reminiscent of the Sublime, suggesting that engaging with the African landscape is a terrifying but uplifting experience. Most of the adjectives describe positive qualities and the only negative image, the simile comparing the rivers to snakes, is tempered both by being associated with silver, and therefore wealth, and by occurring in a sentence which compares the landscape to a "map," that is to say something which the educated white man can read and understand.

Close up the river is even more attractive. Just as Schreiner's description of England is coloured by her familiarity with Africa, so Rider Haggard's description of Africa is marked by his Englishness:

The brook, of which the banks were clothed with dense masses of a gigantic species of maidenhair fern interspersed with feathery tufts of wild asparagus, babbled away merrily at our side, the soft air murmured through the leaves of the silver trees, doves cooed around, and bright-winged birds flashed like living gems from bough to bough. It was like Paradise. (99)

Merry babbling brooks, "soft air" and cooing doves belong in the English countryside and are a long way from the oppressive heat and the harsh cry of parrots or the raucous trumpeting of the hadedah. Once again there is the 
suggestion of treasure with the "silver trees" and "living gems," and the key word is, of course, "Paradise."

Schreiner's publishers obviously thought that Africa had commercial potential. Not only does the title itself, which was not Schreiner's original choice, include the word "African" but the cover of the first edition had an ostrich and a palm tree on it. However, from the very first page it must have been clear to readers that this was not a typical African adventure story. The book opens not in England or on a ship but directly in Africa, and it is an Africa which seems devoid of any form of life:

The full African moon poured down its light from the blue sky into the wide, lonely plain. The dry, sandy earth, with its coating of stunted 'Karoo' bushes a few inches high, the low hills that skirted the plain, the milk-bushes with their long, finger-like leaves, all were touched by a weird and an almost oppressive beauty as they lay in the white light. (35)

Unlike the descriptive passages in Rider Haggard's novels, there is nothing up-lifting about Schreiner's landscape; it has no mountains, only "low hills" and "stunted" vegetation and there is no life-giving water, only "dry, sandy earth." This is no earthly paradise and yet, despite the harshness, the narrator finds it beautiful. Not surprisingly the description of the landscape was remarked upon by contemporary reviewers, but opinion was divided about the accuracy of the description of Africa and whether or not it was stylistically successful. Canon MacColl commented favourably that "The local colouring is extremely vivid," but went on to complain that there was nothing of the Sublime in Schreiner's Africa:

The tendency of ordinary mountain scenery is to raise the spirits, to quicken the imagination, to inspire hope, to point to heaven. The mountains of South Africa, on the other hand, have a depressing influence. They have none of the mystery, the sublimity, the poetry, the aspiration of ordinary mountains. They have no peaks. Their gross bulk and flat tops, and brown sides are altogether of the earth and seem to repel and to forbid man's yearning for something beyond the visible and temporal. (72)

Rider Haggard criticized the novel's plot and setting, bemoaning the lack of exoticism and "wild adventure" (Schreiner 1883 28). In a preface to the second edition of the novel, Schreiner replied to her critics, pointing out that:

Should one sit down to paint the scenes among which he has grown, he [sic] will find that the facts creep in upon him. Those brilliant phrases and shapes which the imagination sees in far-off lands are not for him to portray. Sadly he must squeeze the colour from his brush and dip it into the grey pigments around him. He must paint what lies before him. (ibidem)

Over a hundred years later, when as readers we are familiar with photographs and documentaries about Africa and know that it is a continent with a wide variety of 
vegetation and geological features, it is tempting to say that Schreiner was simply describing a different part of Africa, or, to take a more literary attitude, that since The Story of an African Farm is clearly not an adventure novel, Schreiner was trying to write a more realistic description of the landscape. However, a comparison with a factual description by an English-born writer, Mrs Carey Hobson, shows that this was not the case and that Schreiner was, in fact, proposing a radically new vision of Africa. In Carey Hobson's travel narrative, The Farm in the Karoo: or What Charley Vyvyan and his Friends Saw in South Africa, published the same year as The Story of an African Farm, the same karoo farmland appears far more clement than it does in Schreiner's work:

The whole country around consisted of barren-looking 'flats' but the rows of shady willows, the lofty almond and eucalyptus, forests of peach, apricot and fig and groves of orange and citron trees, irresistibly impressed the beholder with what could be effected by the industry of man. (268)

It is arguably more realistic than the descriptions of Rider Haggard, but it does not dwell on the "barren-looking flats" and draws the reader's attention instead to the prosperity of the farm which has been established there.

The reason for this, I would like to argue, is that like Rider Haggard's novels, Mrs Carey Hobson's work is promoting the ideals of the British Empire. In this respect the last words of this passage, "what could be effected by the industry of man," are particularly significant. Africa is "barren" not for geological and climatic reasons, but because the "primitive" natives and the "uneducated" Boers do not know how to use the land. That Carey Hobson's writing is just as fictitious as Rider Haggard's becomes clear elsewhere in the book when the narrator comments favourably on the "fine pasturage for sheep" (276), and claims that it is a result of the English having improved the climate: "It is very evident that more rain falls in the Karoo at the present time than formerly [...] This is doubtless caused by the greater amount of tree cultivation" (193). These descriptions of green pastures and plentiful rainfall stand in striking contrast to Schreiner's description of drought:

Man and beast turned their eyes to the pitiless sky, that like the roof of some brazen oven arched overhead. On the farm, day after day, month after month, the water in the dams fell lower and lower; the sheep died in the fields [,] the karoobushes were leafless sticks, broken into the earth, and the earth itself was naked and bare; and only the milk bushes, like old hags, pointed their shrivelled fingers heavenwards, praying for the rain that never came. (44)

From her letters it is clear that Schreiner felt a deep attachment to the South African landscape in which she grew up. She writes of the "black nightmare of city life in England" (Rive 192), claims that the karoo "is really very like heaven" (383) and that: "It is my land, my own that I have been longing for in London fogs and summer mist and drizzles, shut in with hedges and those terrible high walls in England that nearly break one's heart" (164). In the end, however, it was 
not a love of literature but politics which led her to write a passionate defence of her country and its people, and she did so not in fiction but in a series of essays. The first of these, "South Africa: Its natural features, its diverse peoples, its political status: The Problem", which Schreiner later described as "a description of South African scenery" (Thoughts, 13), was published in 1891 in Cape Times in South Africa and in The Fortnightly Review in England. Schreiner begins this essay by drawing a distinction between the insider's and the outsider's view of a particular area, arguing that the outsider may seem to have a more objective view of a place, since he is willing to acknowledge its shortcomings, but that:

There is a certain knowledge of a land which is only to be gained by one born in it, or brought into long-continued, close, personal contact with it, and which in its perfection is perhaps never obtained by any man with regard to a country which he has not inhabited before he was thirty. (28)

This distinction leads Schreiner to argue that the problems of South Africa can only be understood by someone who has this knowledge of the land, and her essay is an attempt to impart this knowledge to the English reader. In the first part of the essay, Schreiner adopts the style of a travel narrative and accompanies the reader, who is directly addressed as "you," on a comprehensive tour of South Africa. ${ }^{3}$ Like other nineteenth-century travel narratives, she gives a short description of the major geological features, the climate, the flora and fauna, and the inhabitants of each region. There is an attempt to describe the landscape in terms familiar to English readers and to compare places to European landmarks. Thus the geraniums are those "common in English hot-houses" (33), while the bay at Cape Town is said to be "as blue and delicately curved as that of Naples" (30). The text also flatters English chauvinism by describing the population of Natal as being "largely English and [...] rather above the common Colonial average in intelligence and culture" (35). More interesting, however, is the way the essay subtly undermines the habitual literary conceits used when writing about Africa. Unlike The Story of an African Farm, which was stylistically very much an experimental novel, the essay appears to follow the conventions of the essay genre. This initial impression is, however, misleading. At first sight, for example, the paragraph below would not be out of place in one of Rider Haggard's novels:

There is a certain colossal plenitude, a certain large freedom in all its natural proportions, which is truly characteristic of South Africa. If Nature here wishes to make a mountain, she runs a range for five hundred miles; if a plain, she levels eighty, if a rock, she tilts five thousand feet of strata on end; our skies are higher and more intensely blue; our waves larger than others; our rivers fiercer. There is nothing measured, small nor petty in South Africa. (47)

\footnotetext{
3. She defines South Africa as "all the country south from the Zambezi" (29) which includes not only the whole of South Africa as we know it today but also parts of what are now Namibia, Botswana, Zimbabwe and Mozambique.
} 
However, in what follows it becomes clear that Schreiner's writing is challenging the Sublime. There is nothing overpowering and no idea of terror in the 'excesses' of Africa. Rather its immensity provides a freedom which is both physical and intellectual, and which is not to be found in Europe where overcrowding can "oppress and suffocate" (ibidem). Schreiner also subverts the image of Africa as a bewitching female. In adventure novels, this female leads men to their perdition, but for Schreiner she brings them freedom: "South Africa is like a great fascinating woman; those who see her for the first time wonder at the power she exercises, and those who come close to her fall under it and never leave her for anything smaller, because she liberates them" (ibidem).

It is impossible to talk of a South African writer without taking into account the question of race. Once again, it is useful to take popular novels as a starting point. In adventure novels set in Africa, natives usually appear only to add a touch of background colour or to serve as cannon fodder for the white hero. Occasionally, a black character is given a name and some individuality, but they are never round characters and tend to fall into the category of either faithful or treacherous servant. In adventure novels set in South Africa, the situation was somewhat different, because South Africa had two white populations: the English and the Boers. In the second half of the nineteenth-century, the English saw the Boers not as fellow whites but as another native population. As a result, English novels of this period describe the Boers in terms generally used for black natives in novels set elsewhere in Africa. The Boers are thus usually described as dirty, lazy and lacking any desire to better themselves. In Charlotte Moor's novel Melina de la Rey (1903), for example, they are said to be "a blot upon creation which it was to be hoped the creator might some day wipe out" (140).

Just as Schreiner's novels offered English readers a new vision of the African landscape, so too did they invite readers to question received ideas about the different races present in South Africa. In her two early novels, the distinction between the noble English and the uneducated Boers is blurred. Tant' Sannie in The Story of an African Farm and Mrs Snappercaps in Undine have much in common: both are fat, slovenly and uncultivated, but Tant' Sannie is Afrikaner and Mrs Snappercaps English. The novels suggest that it is the harsh living conditions on South African farms and the lack of prospects available to women which lies at the root of their unpleasant behaviour rather than any 'racial' pre-disposition. The English adventure hero is parodied in The Story of an African Farm through the characters of Bonaparte Blenkins and Gregory Rose. Blenkins is motivated only by self-interest. He has no qualms about lying and using physical violence to obtain what he wants, and his brief stay on the farm has disastrous consequences for the children. As for Gregory Rose, his noble lineage is an invention. He writes on pink paper, and to arrive at the bedside of the woman he loves, he has to shave off his beard and dress as a woman. As Stephen Gray puts it: "This is the ultimate 
downfall of the virile English frontiers-man and ranger, a humiliation that must rank as blasphemous to hard-core adventure readers" (146).

To modern readers, the lack of Africans in these two novels is, at first sight, somewhat surprising - they appear only occasionally in the background, usually carrying out some menial task. However, as Margaret Lenta has pointed out, this is, in fact, an accurate description of life on a South African farm in the nineteenth-century: "The dependence of whites in all areas of their lives on black labour is faithfully recorded, as faithfully as the sense of the author and her characters that these suppliers of labour are inevitably excluded from the social and intellectual life of whites" (25). As such, these novels offer a far more realistic picture than the often lengthy descriptions of the hordes of natives encountered in the pages of Rider Haggard's novels. That said, Schreiner's ideas about race evolved throughout her life, and her two later novels deal with the subject very differently. In From Man to Man, which she worked on throughout her life and which was still unfinished at her death, some twenty-five pages are devoted to a conversation Rebekah has with her sons about racial difference. Rebekah tells her sons the story of the arrival of a superior race from another planet who despise and enslave the English. This story forms what Margaret Lenta calls "a moving parable of the plight of blacks as Schreiner has seen it" (27). Rebekah then goes on to explain to her sons that it is not "the colour or the shape of the jaw or the cleverness that mattered" (437), that all people can love and feel pain, that diversity should be celebrated, not despised, and that the future of South Africa lies in breaking down the walls that the English have built between the races.

Trooper Peter Halket of Mashonaland (1897) offers a different, but equally radical, view of the black population. Peter Halket describes the Africans as a people defending their land in exactly the same way as the English would defend England against the French, and, in what was a daringly new idea at the time, argues that they should therefore be treated in the same way as any other prisoners of war:

these niggers were men fighting for their country; we would fight against the French if they came and took England from us; [...] and if we have to fight against them we ought to remember they're fighting for freedom; we shouldn't shoot wounded prisoners when they were black if we wouldn't shoot them if they were white. (223-24)

So radical were the ideas in this novel that it earned Schreiner the hatred of English-speaking South Africans, who could not forgive her for attacking Rhodes (First \& Scott 222). Despite its notoriety, however, Schreiner considered it a failure, since it did not bring about a change in people's attitudes. As she wrote in a letter to her brother Will, "In spite of its immense circulation [...] I do not believe it has saved the life of one nigger" (First \& Scott 231).

Reading Schreiner's essays after reading her novels comes as something of a disappointment, since they are, in many ways, far more conventional than her 
fiction. Schreiner had initially intended Thoughts on South Africa to have a chapter on all the different races in South Africa, but the essay on black Africans was never written (First \& Scott, 195) and most of the book deals with the Boers. It is possible to argue that in the context of the Boer War, it was more important to try and change the English perception of the Boers than to try and change their perception of the native inhabitants of the country, but the fact remains that when writing of the African population, Schreiner appears to have been unable to go beyond the prevailing racist stereotypes. The Hottentots, for example, are described as being "incapable of bearing a long-continued intellectual or emotional strain" (95-96), while the Bushmen "seem to resemble not so much a race of children as a race caught in the very act of evolving into human form" (96), and they use a language "said by those who have closely studied it to be so imperfect that the clear expression of even the very simplest ideas is difficult" (97).

There is a tendency to think that essays provide a more accurate, or at least a more objective, account than fiction does. Schreiner's work, however, would seem to suggest that this is not always the case, and that on some occasions a novel, perhaps because as a genre its conventions are less fixed, is able to articulate what an essay cannot. In Schreiner's case, fiction was a way for her to offer a radical vision of South Africa in which no one race was superior to another. However, I would like to argue that an equally, if not more important legacy is to be found in her descriptions of the landscape, for as Simon Schama writes: "National identity [...] would lose much of its ferocious enchantment without the mystique of a particular landscape tradition: its topography, mapped, elaborated and enriched as a homeland" (15). Familiar as we are today, not only with all the New Literatures in English, but also with works translated from many different languages and cultures, it is difficult to appreciate quite how innovative Schreiner's descriptions of the African landscape were. However, as the contemporary South African novelist Dan Jacobson reminds us, until recently it was unusual to find anything other than the English world view in a novel. He says of his own childhood: "I had to struggle with my own incredulity that the kopjes, kraals and cactus plants [Schreiner] mentions were of the same kind as those I was familiar with: so little experience had I had of encountering them within the pages of a book" (18). Schreiner was the first to describe Africa from the inside, and in so doing paved the way not only for the development of South African literature, but also for the development of the different national literatures of the countries which made up the British Empire.

Susan BARRETT

Université de Bordeaux 3 


\section{Works Cited}

Barrett, Susan. "Oh to be in Africa now that April's there: Demythologising the Motherland in White South African Women's Writing." In Mythologies of the (M) otherland: Mythologies de la mère patrie et de la terre d'accueil. Ed. Evelyne HanquartTurner. Ivry-Sur-Seine : Editions A3, 2004.

Bradford, Helen. "Olive Schreiner's Hidden Agony: Fact, Fiction and Teenage Abortion.” Journal of Southern African Studies, 21.4 (1995): 623-641.

Boenmer, Elleke. Colonial and Postcolonial Literature. Oxford: Oxford UP, 1995.

Bunn, David. "Embodying Africa: Women and Romance in Colonial Fiction" English in Africa 15.1 (May 1988): 1-27.

Darian-Smith, Kate, Liz Gunner, Sarah Nuttall, eds. Text, Theory, Space: Land, Literature and History in South Africa and Australia. London: Routledge, 1996.

First, Ruth \& Ann Sсотт. Olive Schreiner: A Biography. London: André Deutsch, 1980.

Gray, Stephen. Southern African Literature: An Introduction. Cape Town: David Philip, 1979.

Green, Martin. Dreams of Adventure, Deeds of Empire. London: Routledge \& Kegan Paul, 1980.

Haggard, Henry Rider. Allan Quatermain. 1887. Harmondsworth: Puffin, 1990.

—. King Solomon's Mines. 1885. Harmondsworth: Penguin Popular Classics, 1994.

Hobson, Mrs J. Carey. The Farm in the Karoo or What Charley Vyvyan and his Friends Saw in South Africa. London: SPCK, 1883.

Jacobson, Dan. "Introduction" to Olive Schreiner, The Story of an African Farm. Harmondsworth: Penguin Classics, 1986.

Laredo, Ursula. “Olive Schreiner." Journal of Commonwealth Literature 8 (1969): 107-24.

Lenta, Margaret. "Racism, Sexism and Olive Schreiner's Fiction.” Theoria 70 (October 1987): 15-30.

McColl, Canon. "An Agnostic Novel: Review of The Story of an African Farm." The Spectator (13 August 1887). In Cherry Clayton, ed. Olive Schreiner. "South African Literature Series.” Isando: McGraw-Hill, 1983.

Moor, Charlotte. Marina de la Rey. London: Digby, Long, 1903.

RIve, Richard, ed. Olive Schreiner Letters Volume 1: 1871 - 1899. Oxford: Oxford UP, 1988.

Schama, Simon. Landscape and Memory. London: Fontana, 1996.

Schoeman, Karel. Only an Anguish to Live Here: Olive Schreiner and the Anglo-Boer War 1899-1902. Cape Town: Human \& Rousseau, 1992.

Schreiner, Olive. The Story of an African Farm. A novel in two volumes. London: Chapman \& Hall, 1883. Harmondsworth: Penguin, 1986.

—. Trooper Peter Halket of Mashonaland. London: T. Fisher Unwin, 1897. 
-. Woman and Labour. London: T. Fisher Unwin, 1911.

—. Thoughts on South Africa. 1923. Johannesburg: Ad Donker, 1992.

—. From Man to Man; or Perhaps Only. London: T. Fisher Unwin, 1926.

—. Undine. New York/London: Harper \& Bross, 1928.

Zhuwarara, Rino. "Heart of Darkness Revisited: The African Response." Kunapipi 16.3 (1994): 23-37. 